\title{
European Seismic Risk Model 2020: Focus on Croatia
}

\author{
Helen Crowley \\ Vitor Silva \\ Venetia Despotaki \\ Luis Martins \\ Josip Atalić
}

\author{
Helen Crowley \\ European Centre for Training and Research in Earthquake Engineering \\ (EUCENTRE), Pavia, Italy \\ Vitor Silva, Venetia Despotaki, Luis Martins \\ GEM Foundation, Pavia, Italy \\ Josip Atalić \\ Faculty of Civil Engineering, University of Zagreb, Croatia \\ Corresponding author: Helen Crowley, helen.crowley/deucentre.it
}

https://doi.org/10.5592/CO/FTCE.2019.03 


\section{European Seismic Risk Model 2020: Focus on Croatia}

Abstract

This paper summarises the development of the European seismic risk model that is being undertaken within the Horizon 2020 SERA project in collaboration with the Global Earthquake Model (GEM) Foundation. The main innovation of the current effort with respect to previous initiatives relates to the extension of seismic risk to 46 countries within Europe, the use of a fully probabilistic methodology, the consideration of socio-economic aspects, and the involvement of the local scientific community in the development of the models. Some specific details of the European risk model for Croatia are also presented, together with some preliminary results.

Key words: seismic risk, seismic hazard, Croatia, exposure, vulnerability

\section{Europski model seizmičkog rizika 2020: fokus na Hrvatsku}

\section{Sažetak}

U radu je sažeto prikazan razvoj europskog modela seizmičkog rizika koji se provodi u sklopu Horizon 2020 projekta SERA u suradnji sa zakladom Global Earthquake Model (GEM). Glavna novost u sadašnjem projektu u odnosu na prethodne inicijative obuhvaća proširenje seizmičkog rizika na 46 zemalja unutar Europe, primjenu potpuno probabilističke metodologije, razmatranje društveno-ekonomskih aspekata i uključenost lokalne znanstvene zajednice u razvoj modela. Detalji europskog modela rizika, specifični za Hrvatsku, također su prikazani, kao i neki preliminarni rezultati.

Ključne riječi: seizmički rizik, seizmička opasnost, Hrvatska, izloženost, oštetljivost 


\section{Introduction}

Several large-scale European projects have covered aspects of seismic risk over recent years, from seismic hazard (SHARE - www.share-eu.org), to structural fragility/ vulnerability (Syner-G - www.vce.at/SYNER-G) to building exposure (NERA - www. nera-eu.org). This paper describes the development of the first harmonised European seismic risk model that is being carried out as part of the Horizon 2020 SERA project (Seismology and Earthquake Engineering Research Infrastructure Alliance for Europe). This model will generate a number of risk metrics (average annualised losses, probable maximum losses, risk maps), critical for the development of seismic risk reduction strategies. Herein we present a summary of the activities towards the development of an exposure model, a set of fragility/vulnerability functions, and the calculation of probabilistic seismic risk at the European scale. Some specific details of the European risk model for Croatia at month 24 of the project are also presented, together with some preliminary results. The v1 European risk model will be released in April 2020 through the European Seismic Risk Service (http://eu-risk.eucentre.org) and is expected to be continually updated and improved in the future in collaboration with local experts.

\section{European Seismic Risk Framework}

A probabilistic seismic risk assessment (PSRA) involves the estimation of the probability of damage and losses resulting from potential future earthquakes. This damage and loss might occur to buildings, infrastructure, people or even the environment. Within the European risk framework that is being developed within the SERA project, the focus is being placed on estimating physical damage and loss for residential, commercial and industrial buildings (and their occupants), by combining seismic hazard (i.e. probability of exceeding different levels of surface ground shaking) with physical vulnerability and exposure models:

PHYSICAL SEISMIC RISK = SEISMIC HAZARD $\otimes$ EXPOSURE $\otimes$ PHYSICALVULNERABILITY

The calculations for the European probabilistic seismic hazard and risk assessments are being undertaken with the OpenQuake-engine [I, 2], using the event-based probabilistic risk assessment module (Figure I). This calculator requires an exposure model, a physical vulnerability model and a set of ground motion fields, which represent the spatial distribution of the ground shaking at the surface. The latter are produced through the hazard library of the OpenQuake-engine (hazardlib). One of the inputs to the hazardlib is a seismogenic source model (which models the spatial and temporal occurrence of earthquake activity) that is used to create an earthquake rupture forecast (i.e. list of all of the possible ruptures that can occur in the region of interest), which is then employed to generate stochastic event sets (SES). Due to the random nature of the process, a large number of SES is required in order to 
reach statistical convergence in both the seismic hazard and risk assessments [3].The epistemic uncertainty in the seismogenic source model can be propagated through the use of logic trees [I]. For each event in the SES, a ground-motion field will be generated, considering one or multiple ground-motion prediction equations (GMPEs, described through a ground motion logic tree) associated with the respective tectonic region as well as the local site conditions. The intra- and inter-event aleatory variability from the GMPEs is propagated using a Monte Carlo approach, and the spatial correlation in the ground motion residuals from the same intensity measure (e.g. a given spectral ordinate) can be considered using the correlation model from Jayaram and Baker [4].

The surface ground shaking at a given coordinate will be combined with the physical vulnerability functions (see Section 5) for the building classes identified at that location, and multiplied by their replacement costs / number of occupants (as defined in the exposure model, see Section 4) to compute the expected loss for each event in the SES. This will lead to the derivation of event loss tables, comprising the losses per building class and location for each event in the SES. These tables can be used for the calculation of several risk metrics, including exceedance probability curves and average annualized losses. The former metric expresses the rate of exceeding $(\lambda)$ a given loss I, as described by Eq. (2):

$$
\lambda(L>I)=\frac{1}{n} \sum_{i=1}^{j} I\left(L_{i}>I\right)
$$

where I $(L i>I)$ stands for the number of loss values above I, $j$ is the total number of losses, $L i$ stands for the loss caused by event $\mathrm{i}$, and $\mathrm{n}$ represents the length of the SES. Likewise, the average annual loss $(A A L)$ can be computed using the following equation:

$A A L=\frac{1}{n} \sum_{i=1}^{j} L_{i}$

These metrics will be calculated for each branch of the logic tree, leading to a probabilistic distribution of risk, from which the weighed AAL (in terms of human loss, economic loss or number of collapsed buildings) can be calculated. For a holistic view of the seismic risk, the physical risk indicators will be combined with social vulnerability, resilience and recovery indices to produce so-called "impact maps". All of the inputs presented in Figure I are required regardless of the scale of the calculation (i.e. local, national or continental). The main differences when running calculations from one scale to another will generally be found in the exposure model, which is more likely to be at a higher resolution for local level risk assessments. Similarly, the site model might have additional geotechnical information, which would allow different approaches to be used to amplify the ground motions (see Section 3). Custom inputs for the seismogenic source model, ground motion model and physical 
vulnerability model can be provided by the user for a local level assessment, whereas the SERA project will develop and release a set of models to be used for seismic risk assessment at the national or continental scale.

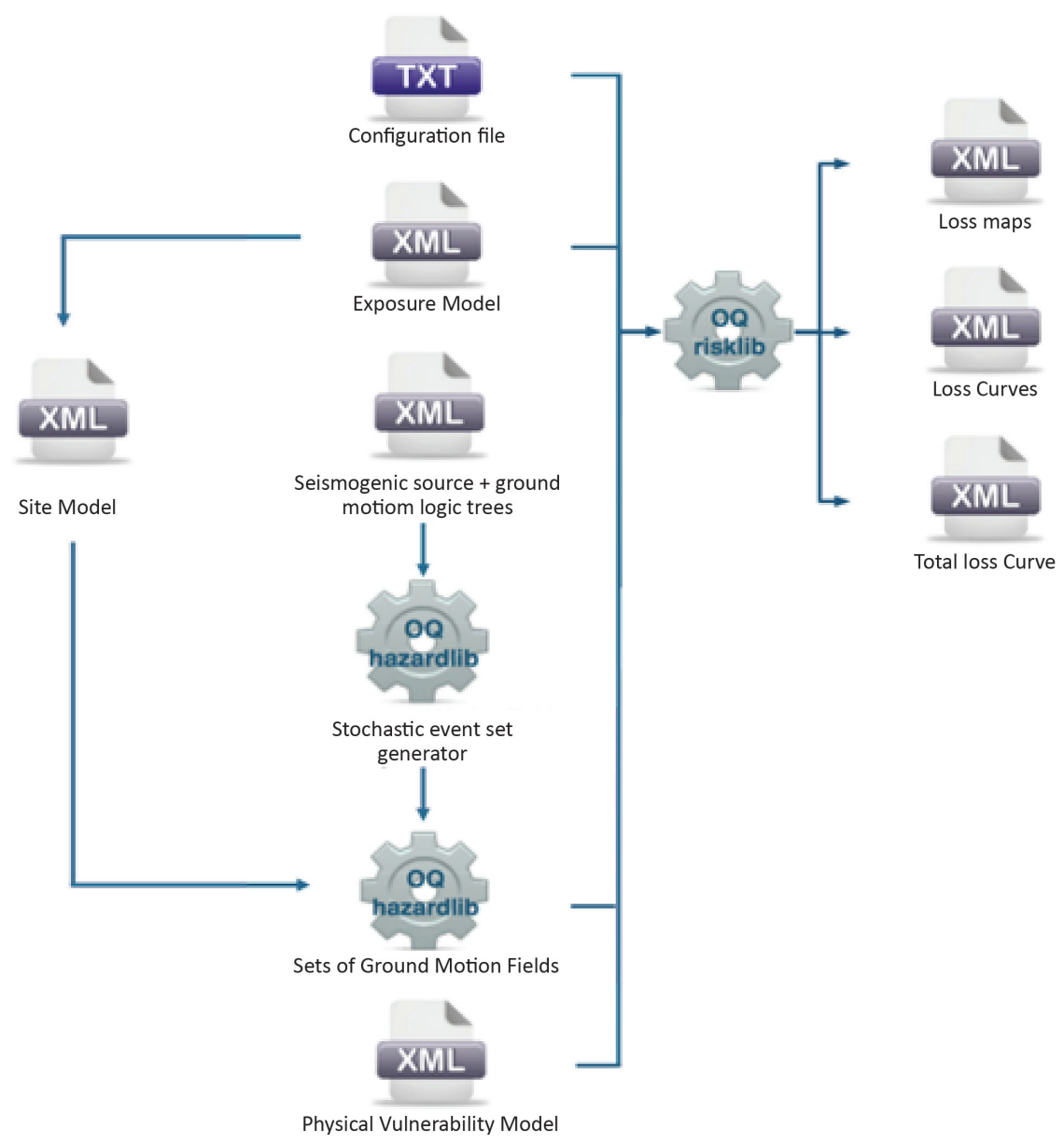

Figure I. European Seismic Risk Framework described using the OpenQuakeengine Probabilistic Event-based Risk Calculator input/output structure 


\section{European Hazard Model}

The latest European seismic hazard model (2013 Euro-Mediterranean Seismic Hazard Model - [5]) is currently available for download through the EFEHR platform (http:// www.efehr.org/en/home/). Users of the EFEHR platform can access pre-computed hazard products such as the spatial distribution of the spectral acceleration on reference bedrock for a number of periods of vibration (from 0.01 to 4 seconds) for a number of return periods $(73,102,475,975,2475,4975$ years). An effort to update the European seismic hazard model is currently being carried out, with updates to the historical and instrumental catalogues, the active fault database, and the logic trees of seismogenic source zones and ground motion models, with the updated hazard model available from April 2020. Given that a seismic risk assessment requires an estimate of the ground shaking at the surface, one of the tasks within the SERA project has been to consider how the aforementioned seismogenic and ground motion logic tree models can be used together with local site conditions to produce probabilistic estimates of surface ground shaking. At the European scale, proxy datasets of 30 arcsecond slope data [6] and an updated European map of geological units developed within the SERA project (see Figure 2) will be used as input for a newly developed geologically-calibrated slope amplification model [10]. It is noted that the additional variability in the estimated ground motions that arises from the use of proxy datasets (i.e. topography and geological units) is explicitly accounted for in the aleatory variability of this amplification model.

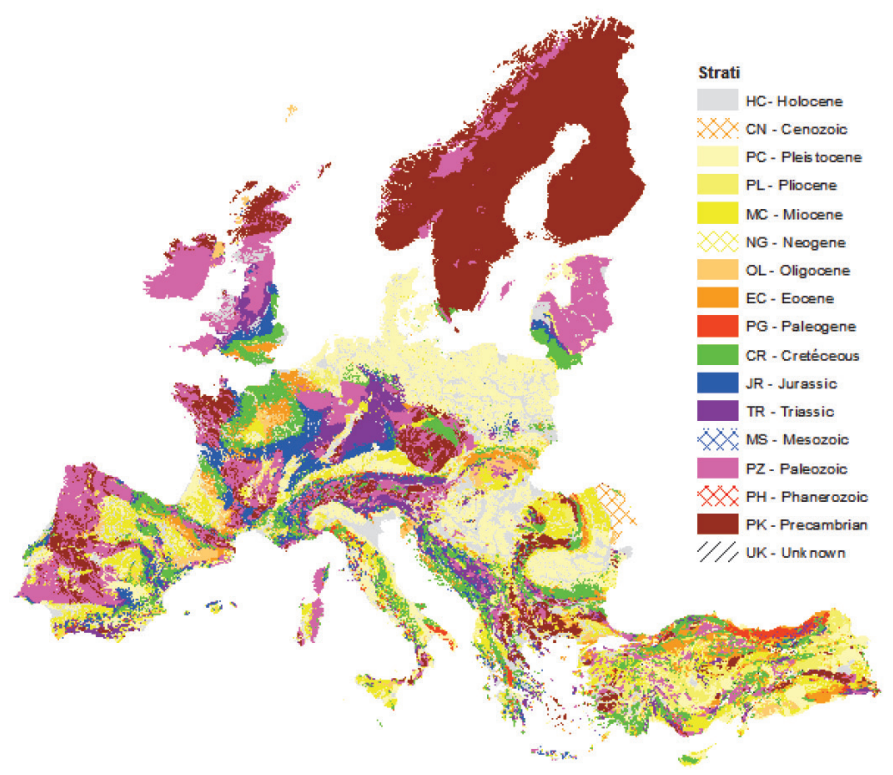

Figure 2. European harmonised stratigraphic map 


\section{European Exposure Model}

The European Exposure Model (i.e. the spatial distribution of the residential, commercial and industrial building count, population, and replacement cost classified according to a number of building classes) being developed in the SERA project is summarised in three deliverables: D26.I, D26.2 and D26.3 [8, 9, 10]. The latter deliverable (D26.3) provides an overview of the exposure model that covers residential, industrial and commercial buildings, at the current stage of the project (month 24). The buildings in Europe are being described using an updated version of the GEM Building Taxonomy ([I I], as updated by [I2]) that allows buildings to be classified according to a number of structural attributes. The following main attributes have been selected for the consistent definition of building classes across Europe in the version 0.2 of the exposure model (currently under development):

- Main construction material (reinforced concrete, unreinforced masonry, reinforced/confined masonry, adobe, steel, timber).

- Lateral load resisting system, LLRS (infilled frame, moment frame, wall, dual frame wall system, flat slab/plate or waffle slab, post and beam).

- Number of storeys.

- Seismic design code level (CDN: pre-code, CDL: low code, CDM: moderate code, $\mathrm{CDH}$ : high code).

- Lateral load coefficient used in the seismic design.

\subsection{Evolution of seismic design in Croatia}

The first seismic design code in the Ex-Yugoslavian countries was adopted in 1964 (Temporary Technical Regulations for Construction in Seismic Regions, Official Gazette of SFRY No. 39/64, 1964), and it made use of the 1950 Seismic Zoning Map of Yugoslavia [13]. Hence all buildings constructed before 1964 have been assigned to the seismic design code level CDN (pre-code). The first major update to this code was made in 198I [14]. In 1990 the seismic design regulations for buildings of category II and III (residential, and administrative, public and industrial buildings not classified in category I) made use of a Seismic Zoning Map related to maximum expected intensities for a return period of 500 years. However, due to the Yugoslav Wars, the 1990 seismic zonation maps were never actually applied in Croatia. Hence, the buildings in the exposure model for Croatia are assumed to have low code level (CDL) from 1964 to $198 \mathrm{I}$ and moderate code level (CDM) from 198I onwards. As the buildings in the census (see Section 4.3) are only available until 20 I I, no buildings have been assigned to $\mathrm{CDH}$ (high code), as Eurocode 8 [15] has only recently been introduced in Croatia.

The seismic zonation maps used with the 1964 and I $98 \mathrm{I}$ codes have been digitised, as shown in Figure 3.The lateral force coefficient (which is the percentage of the weight of the building that is applied horizontally in the design) has been calculated for each zone as follows: 
$\beta=K_{0} K_{s} K_{d} K_{p}$

where $K_{0}$ is a coefficient that depends on the importance of the building, $K_{s}$ is a coefficient based on the seismic intensity of the zone (taken from Figure 3 ), $K_{p}$ refers to the coefficient based on expected ductility and damping, and $K_{d}$ is the dynamic response coefficient that accounts for the period of vibration of the structure. It is noted that the $K_{0}$ and $K_{d}$ coefficients are not present in the 1964 design code. The values of lateral load coefficient vary from 3.75 to $15 \%$ for the low code and from 2.5 to $10 \%$ for the moderate code.

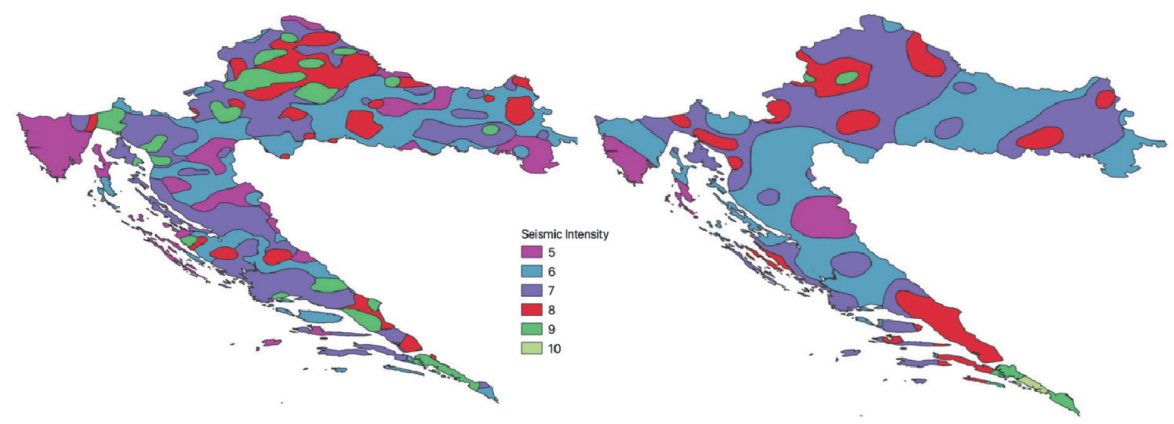

Figure 3. Seismic zonation for Croatia in I 964 (left) and I 98 I (right) seismic design codes

The design code and lateral force coefficients are then assigned to the reinforced concrete buildings in the exposure model as a function of their age and location, so that they can be mapped to the vulnerability models, which can make use of simulated design based on the design code and lateral force, as discussed in Section 5.

\subsection{Residential exposure model for Croatia}

In order to identify the residential building classes that are present in Croatia, advice from local experts have been sought through workshops and questionnaires. The building classes used in the exposure model are summarised in Table I (though it is noted that not every combination of the attributes from each column in Table $I$ is found in the exposure model).

The 20II Population and Housing Census (https://www.dzs.hr/) has been used to describe the spatial distribution of residential buildings. However, these data only provide the distribution of population and dwellings within each municipality (urban or rural) of Croatia. The number of dwellings in terms of year of construction was provided at a national level and the proportion of buildings in each building area has been assumed to be the same within each municipality. The year of construction has been used to develop a mapping scheme to distribute the building classes within the exposure model, based on the following main assumptions: 
- Buildings are either constructed with reinforced concrete or masonry (confined and unreinforced) and the relative percentage of each has been defined by the input from local experts;

- Rural areas do not have buildings with more than 6 storeys;

- Until 1945, there were only unreinforced masonry buildings in the rural areas;

- The masonry buildings constructed before 1980 are assumed to be unreinforced and after $198 \mathrm{I}$ are considered to be confined in both rural and urban areas;

- The reinforced concrete buildings are assumed to have either an infilled frame or dual wall-frame lateral load resisting system (with the latter only found in urban areas).

Table I. Summary of residential building classes in the Croatia exposure model. The GEM Building Taxonomy attributes are given in brackets

\begin{tabular}{|c|c|c|c|c|}
\hline $\begin{array}{l}\text { Material of } \\
\text { LLRS }\end{array}$ & LLRS & $\begin{array}{c}\text { Number of Sto- } \\
\text { reys } \\
\text { (H or HBET) }\end{array}$ & Design Code & $\begin{array}{l}\text { Lateral Load } \\
\text { Coefficient [\%] }\end{array}$ \\
\hline \multirow[b]{2}{*}{$\begin{array}{l}\text { Cast-in-place rein- } \\
\text { forced concrete } \\
\text { (CR) }\end{array}$} & $\begin{array}{l}\text { Dual wall-frame } \\
\text { (LDUAL) }\end{array}$ & $\begin{array}{l}3-5 \\
6+\end{array}$ & CDM & $\begin{array}{c}0 \\
2.5 \\
5.0 \\
10\end{array}$ \\
\hline & $\begin{array}{l}\text { Infilled frame } \\
\text { (LFINF) }\end{array}$ & $\begin{array}{c}1 \\
2 \\
3-5 \\
6+\end{array}$ & $\begin{array}{l}\text { CDN } \\
\text { CDL } \\
\text { CDM }\end{array}$ & $\begin{array}{c}0 \\
2.5 \\
3.75 \\
5.0 \\
7.5 \\
10 \\
15\end{array}$ \\
\hline $\begin{array}{l}\text { Unreinforced } \\
\text { Masonry (MUR) }\end{array}$ & Wall (LWAL) & I, 2, 3-5 & CDN & $\mathrm{N} / \mathrm{A}$ \\
\hline $\begin{array}{c}\text { Confined Masonry } \\
\text { (MCF) }\end{array}$ & Wall (LWAL) & I, 2, 3-5 & $\begin{array}{l}\text { CDN } \\
\text { CDL }\end{array}$ & $\mathrm{N} / \mathrm{A}$ \\
\hline
\end{tabular}

The average area per dwelling for each building class was defined by distributing the total residential floor area provided by the Croatian Bureau of Statistics among the building classes, while taking into account that single-family detached buildings (commonly found with one or two storeys) tend to have larger area compared to dwellings within apartments (commonly found with more than three stories). The assumptions regarding the average area per dwelling are shown in Table 2 . In order to capture the spatial variability between different settlement types, the replacement cost per square meter was defined separately for urban, rural areas and large cities. In particular, a replacement cost of $800\left(E U R / \mathrm{m}^{2}\right)$ was used for buildings constructed in urban areas, $600\left(E U R / \mathrm{m}^{2}\right)$ for buildings in rural areas, while a cost of $1100\left(E U R / \mathrm{m}^{2}\right)$ was used for buildings located in large cities, such as Zagreb, Split, Rijeka and Osijek. 
In addition, the cost was further differentiated based on the main material used for construction (masonry, adobe, concrete, wood, steel), assuming that reinforced concrete is more expensive than steel, masonry, adobe or wood.

Table 2.Area per dwelling as a function of the height of the building

\begin{tabular}{|c|c|}
\hline Number of storeys & Area per dwelling $\left[\mathbf{m}^{2}\right]$ \\
\hline I & 81 \\
\hline 2 & 76 \\
\hline Between 3 and 5 & 71 \\
\hline More than 6 & 70 \\
\hline
\end{tabular}

The current version of the exposure model has 2.16 million dwellings, 1.6 million buildings (with a total replacement cost estimated at $€ 170$ billion) and 4.28 million people. The national distribution of buildings between the different building classes is shown in Figure 4. The percentage of buildings in most of the reinforced concrete classes is relatively low due to the large number of combinations of design code and lateral load coefficient. The percentage in terms of material of construction and lateral load resisting system is thus shown in Figure 5.

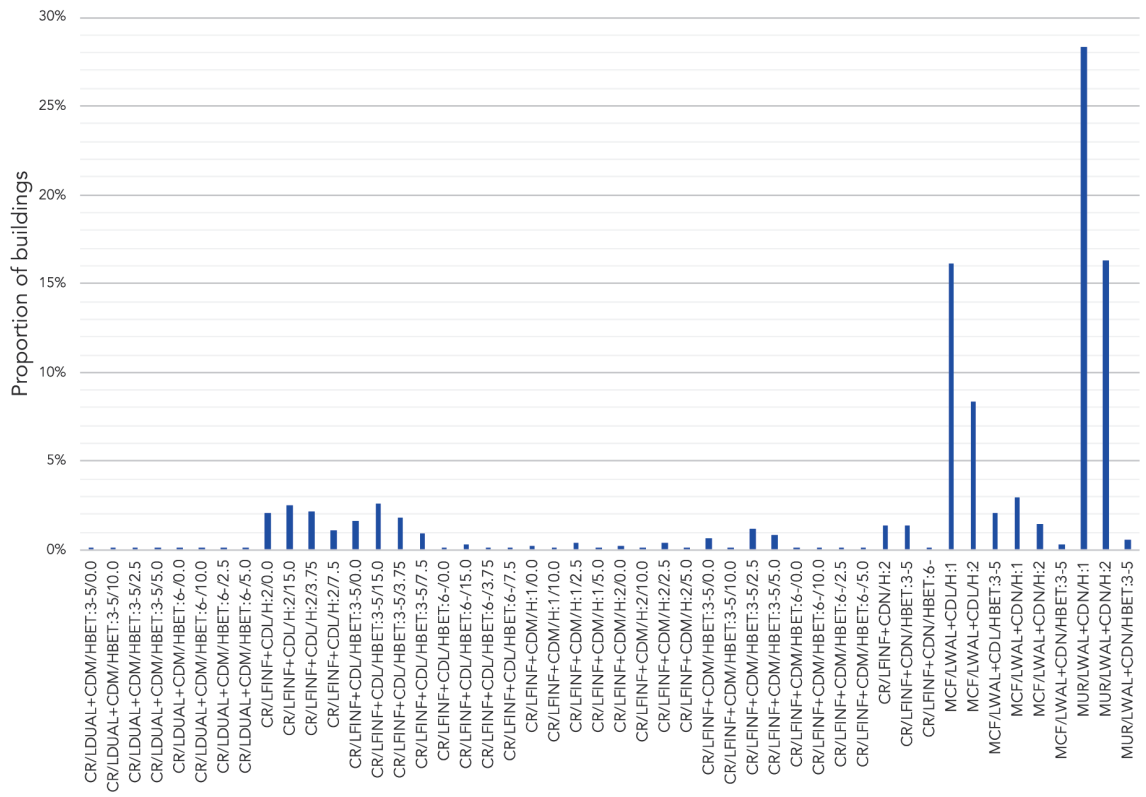

Figure 4. National distribution of the number of residential buildings according to the building classes 


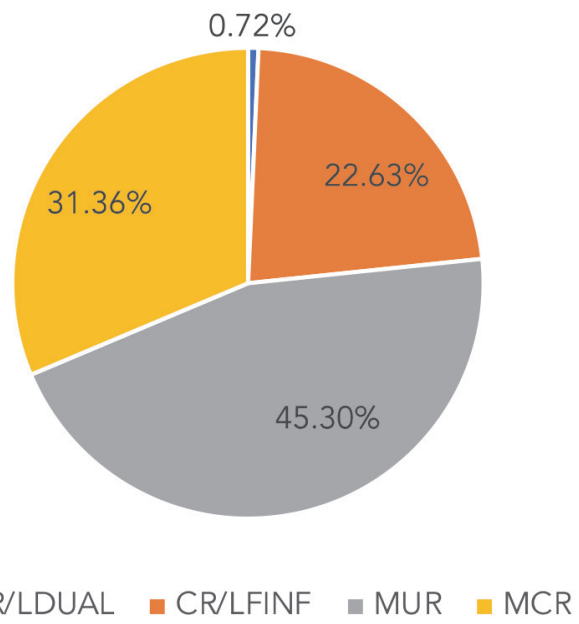

Figure 5. National distribution of residential buildings according to the material of construction and lateral load resisting system

\section{European Physical Vulnerability Model}

The methodology being proposed in the SERA project for developing fragility and consequence models for European buildings is outlined in Deliverable D26.5 and shown in Figure 6 [16].The basic workflow of the framework starts with the definition of the Building Class Information Model (BCIM). The BCIM includes the information that is necessary to compute the total variability of the fragility function associated to a building class. Inside the BCIM, the building class is characterized by its simple collapsed taxonomy (used in the exposure model), and includes information about the attributes that are not explicitly included in the simple taxonomy, as well as statistical information about the architectural properties and design assumptions. Furthermore, the BCIM also includes information available from the SERA.REVIEW database. This database comprises existing/literature information (capacity curves, fragility functions and vulnerability models) and follows the data-structure defined within GEM"s Global Vulnerability Database (https://platform.openquake.org/vulnerability, i.e. data, metadata and model information).

The propagation of the uncertainties and variability sources included in the BCIM to the fragility function is then performed by developing a set of realizations of the BCIM data that represents several possible building realizations of a given building class. Each realization is then analysed in the modelling module, where either a simplified (Type I) or a complex (Type 2) model based on a simulated design approach is created. The information about these models is stored into the fragility information model (FIM). The FIM also includes a set of realizations of the BCIM data, each of which is defined by a numerical model and a set of seismic capacity variables derived 
from nonlinear static analysis. Hence, two types of FIM can be generated by the framework, depending on the type of data stored in the BCIM:

Type I: The FIM is based on a simplified data model, and is based on the main principles used by [17] and [18] to develop existing regional fragility functions. The $\mathrm{BCIM}$ information required for applying this method are approximations for the probabilistic capacity curve parameters and correlations (in the ADRS format) for the building class.

Type 2: The FIM is based on a simulated design approach, thus targeting mainly engineered buildings (i.e. excluding the masonry building classes). By using statistical distributions for the architectural building parameters and defining the main design assumptions, a set of buildings can be designed for a given design code level (also connected to the age of the buildings considered for each building class). This design is also performed accounting for the seismic hazard at the site, represented by a lateral load coefficient $(\beta)$. After designing the buildings, a set of nonlinear models of the buildings is developed, and nonlinear static analyses are performed. Hence, the data included in the FIM involve a set of nonlinear 3D models, their corresponding modal properties and statistical distributions of pushover curve parameters.

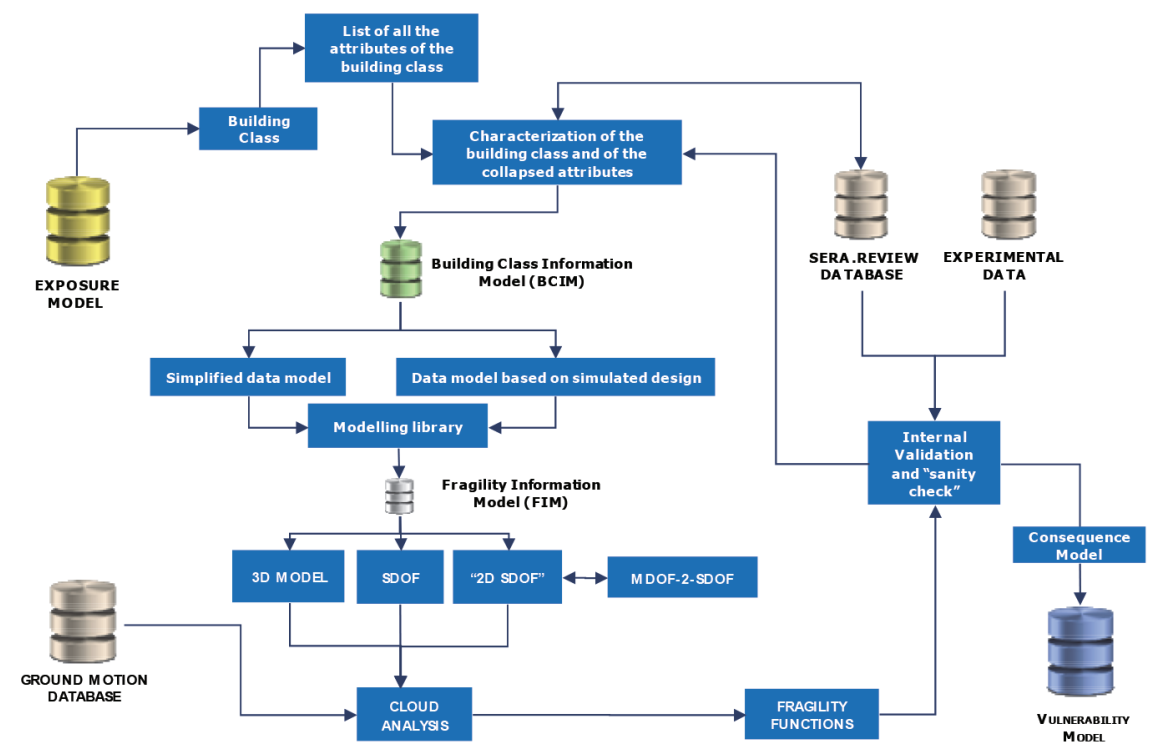

Figure 6. General workflow of the SERA framework for seismic vulnerability analysis

Each realization of the FIM data model is then analysed using a record-to-record uncertainty propagation method (nonlinear dynamic cloud analysis), either using a SDOF, a 2D SDOF or a full 3D MDOF, depending on the complexity of the building class and the existing degree of confidence in the more simplified modelling 
approaches. The records used for the nonlinear dynamic analysis include recordings with PGA greater than 0.05g in the European Strong Motion (ESM: [19, 20]). From the nonlinear dynamic cloud analysis, a best fit curve between the intensity measure level and the nonlinear displacement response is derived in the logarithmic space (Figure 7), after which fragility functions are readily produced using displacement thresholds assigned to each damage state. The SERA methodology proposes the use of AvgSa (i.e. geometric mean of spectral acceleration values over a range of periods) as an optimum intensity measure type, as it has been shown to be a sufficient intensity measure (e.g. [2I, 22]) and it also allows for direct comparison between fragility functions, which is useful for validation purposes (see below). However, for the sake of simplicity and to allow existing hazard results to be directly used without modification, additional intensity measures of PGA, $\mathrm{Sa}(0.3 \mathrm{~s}), \mathrm{Sa}(0.6 \mathrm{~s})$ and $\mathrm{Sa}(\mathrm{I} .0 \mathrm{~s})$ are also considered for the regression.
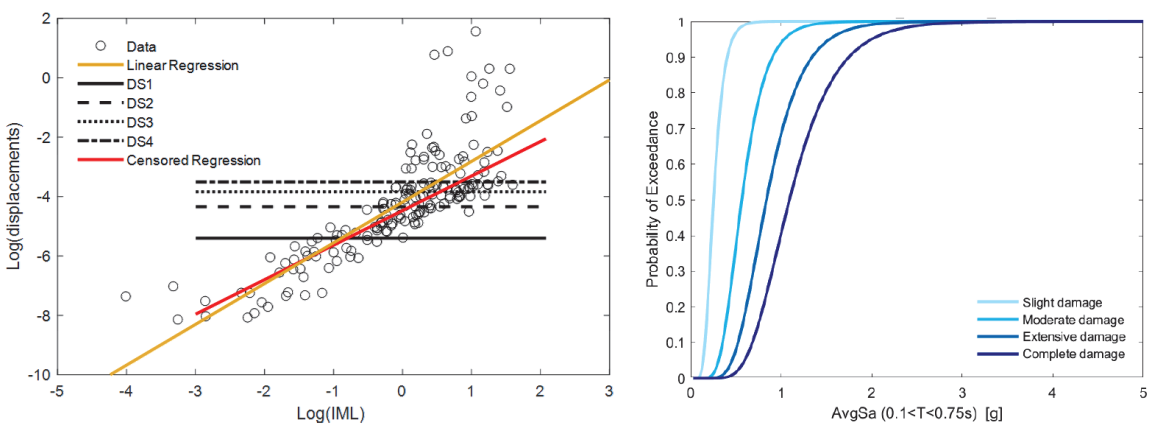

Figure 7. Example of censored regression analysis and resulting lognormal fragility functions

Consequence models, or damage-to-loss models, are used to transform the fragility functions (i.e. probability of reaching or exceeding a set of damage states, conditional on a level of ground motion), to vulnerability functions (i.e. probabilistic distribution of loss ratio conditional on a level of ground motion, see Figure 8). The losses that will be considered in the European Seismic Risk Model will be direct economic loss due to structural and non-structural damage (and thus the loss ratios will represent the ratio of cost of repair to cost of replacement of the buildings) and fatalities (and thus the loss ratios will represent the ratio of the number of fatalities to the number of occupants of the buildings).

Once the fragility and vulnerability models are computed, they are checked according to a set of benchmark case studies to assess their conformity (through "sanity checks" based on the comparison of fragility curves of different building classes) and their "predictability" performance (i.e. by comparing their results with real data from post-earthquake surveys). If a model provides adequate conformity and predictability levels, it is adopted as a good representation for the vulnerability of the building class under analysis. Otherwise, an iterative procedure starts that can involve increasing 
the complexity of the FIM data model and of the techniques used to include recordto-record variability, or improving the consequence models. In case these measures are insufficient, modifications have to be made to consequence model or to the BCIM model.
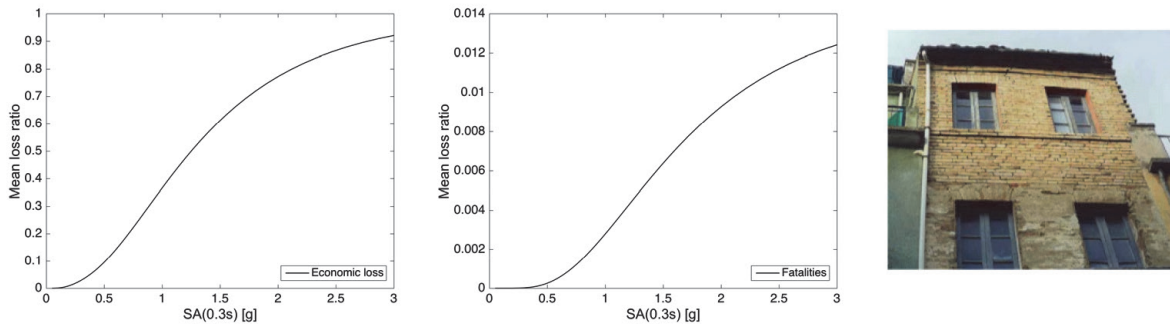

Figure 8. Example vulnerability functions for economic loss and fatalities for a masonry building class

\section{Seismic Risk}

\subsection{Seismic Risk Outputs}

As presented previously in Figure I, the outputs of the risk framework include loss maps, loss curves and total (aggregated) loss curves. The interactive risk maps that will be released on the European Seismic Risk Service (https://eu-risk.eucentre.it/ seismic-risk) will be expressed in terms of average annual loss (AAL), but other results such as exceedance probability curves and aggregated losses for specific return periods will be presented in country profiles, based on those proposed by GEM on the Global Risk Model Explorer (https://maps.openquake.org/map/globalseismic-risk-map). In addition, the following indicators of the Sendai Framework for Disaster Risk Reduction will also be produced by April 2020 and will be included in the country profiles:

AI: Number of deaths attributed to earthquakes, per 100,000 population;

B3: Number of people whose damaged dwellings were attributed to earthquakes;

B4: Number of people whose destroyed dwellings were attributed to earthquakes;

C3: Direct economic loss to all other damaged or destroyed productive assets attributed to disasters;

C4: Direct economic loss in the housing sector attributed to disasters.

\subsection{Physical Risk Results for Residential Buildings in Croatia}

Some preliminary physical risk results have been calculated for Croatia using the ESHMI 3 hazard model, the residential exposure model summarised in Section 4.2 and fragility and vulnerability models developed using Type I capacity curves provided 
by the global database of Martins and Silva [18]. These vulnerability functions do not explicitly account for the lateral load coefficient (for reinforced concrete buildings) and so this part of the model is currently being updated. Nevertheless, these preliminary results are presented in the following plots to illustrative the outcomes of the model and give an indication of the expected range of losses. The loss exceedance curve in terms of the ratio of economic losses to total replacement cost (loss ratio) is given in Figure 9. The average annual loss ratio (AALR) has been calculated (Equation 3) from this plot as $0.042 \%$. Figure 10 shows the spatial distribution of AALR across the country. The three regions with the highest relative losses are Zagreb, KrapinaZagorje and Karlovac County.

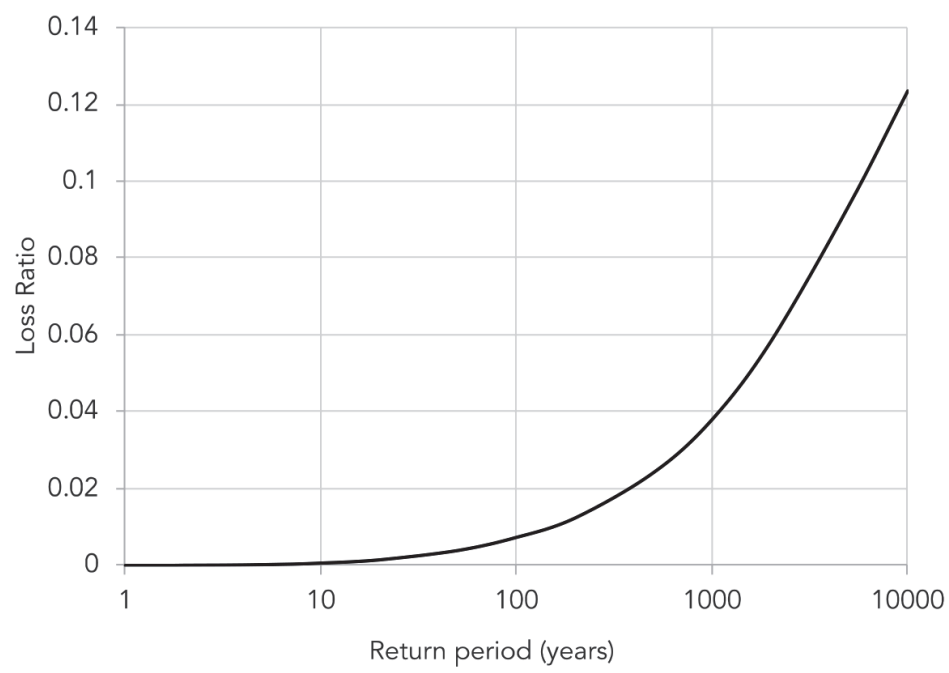

Figure 9. Loss ratio versus return period for the residential building stock in Croatia

\section{Conclusions}

The aim of this paper has been to report the current status of the different model components of the European seismic risk framework being developed in the SERA project, and present how they will be combined for the purposes of a fully probabilistic seismic risk assessment. Some details of the risk model for Croatia have been presented, and these will be discussed further with local experts at an upcoming workshop for the Balkans that will be hosted in Serbia. The risk model components presented herein will continue to be improved during the last 12 months of the project and shared on the European Seismic Risk Service portal (https://eu-risk. eucentre.it). 


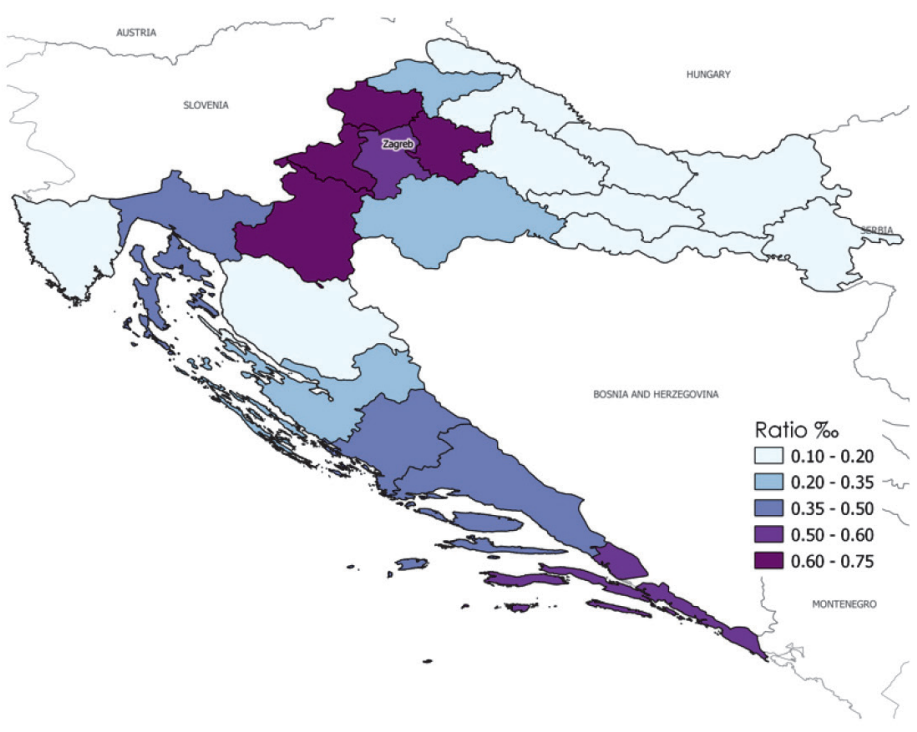

Figure 10.Spatial distribution of AALR in Croatia

\section{Acknowledgements}

The work presented herein is being developed by many researchers - more than those that could be added as co-authors to this paper. A full list of contributors is thus provided here: https://eu- risk.eucentre.it/contributors and all those that have contributed are gratefully acknowledged. Particular thanks are due to M. Uroš, M. Šavor Novak, Z. Sigmund, D. Lazarević, D. Aničić and P. Borović for their contribution to the exposure mapping schemes for Croatia. The work presented herein has received funding from the European Union"s Horizon 2020 research and innovation programme through the research project "SERA" Seismology and Earthquake Engineering Research Infrastructure Alliance for Europe, under grant agreement No.730900.

\section{References}

[I] Pagani, M., Monelli, D., Weatherill, G., Danciu, L., Crowley, H., Silva, V., Henshaw, P., Butler, L., Nastasi, M., Panzeri, L., Simionato, M. and Vigano, D.: OpenQuake Engine:An open hazard (and risk) software for the Global Earthquake Model, Seismological Research Letters, 85 (2014) 3, pp. 692-702.

[2] Silva, V., Crowley, H., Pagani, M., Monelli, D., Pinho, R.: Development of the OpenQuake engine, the Global Earthquake Model"s open-source software for seismic risk assessment, Natural Hazards, 72 (2014) 3, pp. I409-1427. 
[3] Silva, V.: Critical Issues on Probabilistic Earthquake Loss Assessment, Journal of Earthquake Engineering, (2017), doi: http://dx.doi.org/10.1080/I3632469.2017.1297264

[4] Jayaram, N., Baker, J.: Efficient sampling and data reduction techniques for probabilistic seismic lifeline risk assessment, Earthquake Engineering and Structural Dynamics, 39 (2010) I0, Pp. I I09-I I 3 I.

[5] Woessner, J., Danciu, L., Giardini, D., Crowley, H., Cotton, F., Grunthal, G., Valensise, G., Arvidsson, R., Basili, R., Demircioglu, M., Hiemer, S., Meletti, C., Musson, R., Rovida, A., Sesetyan, K., Stucchi, M.: The 2013 European Seismic Hazard Model - Key Components and Results, Bulletin of Earthquake Engineering, I 3 (20I5) I2, pp. 3553-3596, doi:I0.I007/s I05 I8-0I5-9795-I.

[6] Becker, J. J., Sandwell, D. T., Smith, W.H.F., Braud, J., Binder, B., Depner, J. L., ... \& Ladner, R.: Global bathymetry and elevation data at 30 arc seconds resolution: SRTM30_PLUS. Marine Geodesy, 32(4) (2009), pp. 355-37I.

[7] Weatherill, G.W., Kotha, S.R., Cotton F.: Re-thinking Site Amplification in Regional Seismic Risk Assessment, Earthquake Spectra, (2019) under review.

[8] Crowley, H., Despotaki,V., Silva,V., Pitilakis, D., Pitilakis, K., Hancilar, U., Bursi, O., Wenzel, M., di Filippo, R., Castro, J.M.: Deliverable D26.I Taxonomy of European residential, commercial, industrial buildings and industrial plants, SERA Project Deliverable, available at URL:https:/eu-risk.eucentre.it/exposure/, 2017.

[9] Crowley, H., Rodrigues, D., Despotaki, V., Silva, V., Covi, P., Pitilakis, K., Pitilakis, D., Riga, E., Karatzetzou, A., Romão, X., Castro, J.M., Pereira, N., Hancilar, U.: Deliverable D26.2 Methods for developing Euyropean residential exposure models, SERA Project Deliverable, available at URL: https://eu-risk. eucentre.it/exposure/, 2018.

[10] Crowley, H., Despotaki,V., Rodrigues, D., Silva,V., Toma-Danila, D., Riga, E., Karatzetzou,A., Fotopoulou, S., Zugic, Z., Sousa, L., Ozcebe, S., and Gamba, P.: Exposure Model for European Seismic Risk Assessment, Earthquake Spectra, (2019), under review.

[II] Brzev, S., Scawthorn, C., Charleson, A.W., Allen, L., Greene, M., Jaiswal, K., Silva, V.: GEM Building Taxonomy Version 2.0. GEM Technical Report 20I3-02 VI.0.0, I82 pp., GEM Foundation, Pavia, Italy, doi: 10.13117/GEM.EXP-MOD.TR2013.02, available at URL: https://www.globalquakemodel.org/ single-post/20I7/05/I7/GEM-Building-Taxonomy-Version-20, 2013.

[12] Silva,V., Yepes-Estrada, C., Dabbeek, J., Martins, L., Brzev, S.: GED4ALL - Global Exposure Database for Multi-Hazard Risk Analysis - Multi-Hazard Exposure Taxonomy, GEM Technical Report 2018-0I, GEM Foundation, Pavia, 2018

[13] Mihajlovic J. 1950 Seismic Zoning Map of Yugoslavia, Seismological Bureau of F.N.R.Y., Belgrade, 1950.

[14] Technical Regulations for Construction of Buildings in Seismic Regions, Official Gazette of SFRY No. $31 / 81$ (Amendments 49/82, 29/83, $21 / 88$, and 52/90),

[15] CEN: Eurocode 8: Design of structures for earthquake resistance - Part I: General rules, seismic actions and rules for buildings. Comité Européen de normalization, Brussels, Belgium, 2004.

[16] Romão X., Castro J.M., Pereira N., Crowley H., Silva V., Martins L. Rodrigues D.: Deliverable D26.5 European physical vulnerability models, SERA Deliverable, 2019.

[17] Villar-Vega, M., Silva,V., Crowley, H., Yepes-Estrada, C., Tarque, N., Acevedo, A., Hube, M., Santa María, H., Coronel, G.: Development of a Fragility Model for the Residential Building Stock in South America, Earthquake Spectra, 33(2) (20I6), pp. 58I-604.

[18] Martins, L., Silva, V.: A Global Database of Vulnerability Models for Seismic Risk Assessment, Proceedings of the 16th European Conference on Earthquake Engineering, Thessaloniki, Greece, 2018. 
[19] Luzi, L., Puglia, R., Russo, E.: ORFEUSWG5: Engineering Strong Motion Database, version I.0. Istituto Nazionale di Geofisica e Vulcanologia, Observatories \& Research Facilities for European Seismology. doi: $10.13127 /$ ESM, 2016.

[20] Luzi, L., Puglia, R., Russo, E., D”Amico, M., Felicetta, C., Pacor, F., Lanzano, G., Çeken, U., Clinton, J., Costa, G., Duni, L., Farzanegan, E., Gueguen, P., lonescu, C., Kalogeras, I, Özener, H., Pesaresi, D., Sleeman, R., Strollo,A., Zare, M.:The Engineering Strong-Motion Database:A Platform to Access PanEuropean Accelerometric Data. Seismological Research Letters, 87(4) (2016), pp. 987-997.

[2I] Eads, L., Miranda, E., Lignos, D.:Average spectral acceleration as an intensity measure for collapse risk assessment. Earthquake Engineering and Structural Dynamics, 44(I2) (20I5), pp. 2057-2073.

[22] Kohrangi, M., Bazzurro, P., Vamvatsikos, D., Spillatura, A.: Conditional spectrum-based ground motion selection using average spectral acceleration. Earthquake Engineering and Structural Dynamics, 46(I0) (20I7), pp. I667-I685. 